\title{
EDUVELOP
}

\author{
Journal of English Education and Development
}

Volume 1, No. 2, March 2018

ISSN 2597-713X (print)

ISSN 2597-7148 (online)

\section{The Effectiveness of Suggestopedia Method with Wordwall Picture in Increasing Vocabulary Mastery with Learning Disabilities}

\author{
${ }^{1}$ Merlin D \\ STIE (State College Economic Studies)Muhammadiyah Tanjung Redeb \\ E-mail: merlindainaruddin@yahoo.co.id \\ ${ }^{2}$ Siti Hajar Larekeng \\ Muhammadiyah University of Parepare \\ Address. Jl. Ahmad Yani KM. 6, Bukit Harapan, Soreang, South Sulawesi, Indonesia \\ E-mail: sitihajar@umpar.ac.id
}

\begin{abstract}
This study investigates the effects of Suggestopedia method with wordwall picture in increase the vocabulary mastery students of SMPLB Negeri Parepare in academic year 2016/ 2017. This method engages the students' attentions and various fun learning activities which decreased the students' boredom during their learning. Wordwall picture provides the students' illustrations and ideas in their minds. It applied mixed methods research design quantitative and qualitative approaches with single group interrupted time-series design. The population are who students with learning disabilities of SMPLB Parepare in academic year 2016/2017 which consist of 11 students and the sample constitútes consist of 5 students. This research used sampling as a technique of sampling. Based on the quantitative analysis, the result showed that 1) student test were significant accorbing to the questionnaire, the result show thet the students motivation incresed. It means that suggestopedia method with wordwall picture affected the students vocebulary mastery in learning. The result also proved that students interest in learning english has a significant relationship or influence with students vocebulary score. 2) The qualitative data from questionnaire showed that students' motivation increased. It means that Suggestopedia method with wordwall picture affected the students vocabulary, mastery in learning, it proved that Suggestopedia Method with Wordwall Picture able to increase the interest in learning English of the students with disabilities learning
\end{abstract}

Keyword: Suggestopedia Method, Wordwall Picture, Students with learning disabilities 


\section{INTRODUCTION}

Vocabulary development was a process of acquiring new words to use in daily life, and more specifically, the basis for learning any language. Teaching students to develop vocabulary means providing explicit instruction on important words from text and teaching students strategies to help them learned word meanings independently. It was critical for both oral and written vocabulary development to increase as students get older to enable them to comprehend increasingly more complex grade level text (kamil et aL, 2008; loftus \& coyne, 2013).

Students with learning disabilities may had weak oral language skills which directly impacts their vocabulary development. A limited vocabulary hinders a student's ability to be successful in comprehending grade level text, participating in classroom discussions, and doing well on assignments, quizzes and tests. These deficiencies often increased over time, making the need for explicit vocabulary instruction even more pressing for students with language deficiencies due to learning disabilities or problems with language acquisition.

Suggestopedia, a language teaching method developed by Bulgarian psychologist Georgi Lozanov. This method to second language learning combined baroque music and a teacherreading target language material. Lozanov believes that music at 60 beats per minute, which mimics the human heartbeat, helps create a calm, relaxing environment where students lose their fears associated with learning, which lead them to acquire the new language

Vol. 1 No. 2 March 2018 more effectively this method enables students to learn the language in the nice, calm environment in theclassroom during the lessons. The use of a word wall as supported media in a classroom can be a highly effective teaching strategy specially suggestopedia method to improve literacy skills. Word wall activities encourage active student participation. Gestures, such as pointing to key words during a lesson, offer visual reinforcement which can be very helpful for students. Word wall activities engage students while they learn key vocabulary, whether it be learning to explain a word, to compare it to other key concepts, or to spell it.

The researcher provided this research to find out the effects of the suggestopedia method with wordwall picture on the students development of communicative competence in English vocabulary subject and also on students' interest in learning English and to find out the correlation between students' vocabulary and interest in learning English. This research was expected to be valuable information mainly for those involved in English study, such as teachers, students, and also readers. The scope of the research was restricted by discipline which limited to the field of linguistic which talks about vocabulary mastery, content which focused on teaching vocabulary. The researcher teach about Noun, and activity which the researcher would give four stage in teaching vocabulary, such as Presentation, Active concert, passive concert and practice stage. 


\section{Suggestopedia method}

Suggestopedia is a method developed in the 1960's by dr. George Lozanov, a physician and psychiatrist in Sofia, Bulgaria. He became interested in hypnosis and hypermnesia, abnormalmemory capacity,in his medical practice.

Lazanov

stated suggestopediamethod is a humanistic foreign teachingmethod that uses a combination oftechniques, such as physical relaxation andvisualization exercises, affirmations andrelaxing music, based on suggestiveprinciples to strengthen selfesteem andexpand the learner 's memory capabilities,enabling students to learn with greaterspeed, little conscious effort and a greatamount of pleasure.

Some of the key elements ofsuggestopedia include a rich sensorylearning environment (pictures, colour,music, etc.), a positive expectation ofsuccess and the use of a varied range ofmethods: dramatic texts, music, activeparticipation in songs and games. Johnson(1982) cited in Prof Mohamed A. Zaid(2014) evaluated the effects of using collective relaxation techniques on thespelling performance of young learners.She used the experiment on separateexperimental and control groups and could

prove that low functioning students improved significantly with suggestopediaprocedures. The overall results indicated favourable effect on both poor and good spellers.

\section{Wordwall Picture}

A word wall was a group of wordsthat are displaýed on a wall, bùlletiñ board, chalkboard, or whiteboard in a classroom. The walls of words were not used as the only instructional tool for vocabulary development in students classroom. Learners consulted the word wall as a thesaurus and spell-check during writing assignments. They used it as a resource during language development lessons. Coskie \& Davis (2009) discussed the importance of science vocabulary and how students could "develop the ability torecognize and understand the vocabulary of science" (pg. 56). They believed that word walls could be powerful teaching tools when students had continuous and frequent opportunities to interact with posted vocabulary. They also stressed the importance of utilizing word walls to support content instruction. They believed that the most successful word walls are jointly created by students and teachers during instruction. Relating to Jackson and narvaez (2013) found that teaching potential of word walls increases when student-generated material and visual supports including black-line pictures and/or cartoons are arranged to illustrate relationships between words and concepts in order to organize learning

\section{Students' Interest}

Interest was often thought of as aprocess that contributes to learning and achievement. That was, being interested in a topic was a mental resource that enhances learning, which then leads to better 
performance and achievement (Hidi, 1990). Sardiman (2014) stated that interest was the condition that occured when someone see the characterictic of the situation that had correlated with her / his need aor desire. WS Winkel (2004:188) "The interest was defmed as the persistent tendency of subjects to feel interested in the subject or a certain subject and was pleased to learn that the study " while Hilgard (2003:57) gives the formula of interest was as follows "is persisting fendency to pay attention to an enjoy some activity or content" that interest is a permanent tendency to notice and remember some of the activities, attention constantly accompanied pleasure.

\section{Students with Disabilities}

Disabilities Education Act (IDEA) state "children with disabilities" or "students with disabilities" means children or students who require special education because of:

1) Autism means a developmental disability significantly affecting verbal and nonverbal communication and social interaction that adversely affects a child's educational performance. Autism may include autism spectrum disorders such as but not limited to autistic disorder, pervasive developmental disorder, not otherwise specified, and asperger's syndrome.

2) Communication disorder means the impairment of speech articulation, voice, fluency, or the impairment or deviant development of language comprehension and/or expression, or the impairment of the use of a spoken

Vol. 1 No. 2 March 2018 or other symbol system that adversely affects educationalperformance.

3) Deaf blindness means having both hearing and visual impairments, the combination of which causes such severe communication and other developmental and educational problems that the child cannot be accommodated inspecial education programs designed solely for students having hearing or visual impairments

4) Emotional disturbance means acondition exhibiting one or more of the following characteristics over a long period of time and to a marked degree that adversely affects a child's educational performance:

a) An inability to learn that cannot be explained by intellectual, sensory, or health factors;

b) An inability to build or maintain satisfactory interpersonal relationships with peers and teachers;

c) Inappropriate types of behavior or feelings under normal circumstances;

d) A general pervasive mood of unhappiness or depression

e) A tendency to develop physical symptoms or fear sassociated with personal or school problems;

f) The term includes schizophrenia but does not apply to children who are socially maladjusted, unless it is determined that they had anemotional disturbance.

5) Hearing impairment means a hearing condition, whether permanent or fluctuating, that adversely affects a 
child'seducational performance. The term includes those children who are hard of hearing or deaf.

6) Intellectual disability means significantly sub average general intellectual functioning, and includes a student whose intelligence test score is two or more standard deviations below the norm on a standardized individual intelligence test,existing concurrently with deficitsin adaptive behavior and manifested during the developmental period, and that adversely affects a child's educational performance.

7) Orthopedic impairment means a motor disability that adversely affects the child's educational performance. The term includes impairments caused by an anomaly, disease or other conditions (e.g., cerebral palsy, spinal bifida, muscular dystrophy or traumatic injury).

8) Visual impairment means a visual impairment that, even with correction, adversely affects a child's educational performance. The term includes those children who are partially sighted or blind

\section{Method}

The design of this research that applied were Mixed methods research, as Gay (2012:483) proposed mixed methods research design combine quantitative and qualitative approaches by including both quantitative and qualitative data in a single study. It used a mixed-method explanatory research design, which is a two phase design involving both quantitative and qualitative methods, but they were assigned

Vol. 1 No. 2 March 2018 unequal weight (Creswell \& Piano-Clark, 2007).To collect quantitative data, all participants were given the questionnaire, and the students' pretest and posttest score were collected to support the quantitative data. The population of this research contitutes the students with learning disabilities of SMPLB Parepare in academic year 2016 / 2017 which consist of 11 students and the sample constitutes consist of 5 students. The sampling design for this population was purposive sample wherein the potential respondents who had a perfect ability to listen, think and hear were choosen on the basis of their convenience and availability. Therefore, the researcher choosed the students who require special education because of intelectual disabilities.

\section{Result}

Analize The Effects of The Suggestopedia Method With Wordwall Picture on The Students Development Of Competence In English Vocabulary Subject.

Table 2. Scores for Pretest and Posttest

\begin{tabular}{|c|l|l|}
\hline Resp & Pretest & Posttest \\
1 & 56.25 & 96.8 \\
2 & 53.12 & 75 \\
3 & 50 & 96.8 \\
4 & 46.87 & 56.25 \\
5 & 18.75 & 75 \\
\hline
\end{tabular}

givingthe treatment by using suggestopedia method, there were 2 students was in Fair classification (20\%), 3 students were in Poor classification (60\%), and 1 student was in Very Poor classification (20\%). Based on the result above, it could be 
concluded that the students' vocabulary were still low, these was proved from all of the students got fair and very poor values.Based on the result of post test, the table above, it could be concluded that the students' vocabulary were high, these was proved from 4 students got Very Good and Good Classification.

Calculating the Paired T test (one tailed)

\begin{tabular}{|l|l|l|l|l|}
\hline D & $\mathrm{S}^{2} \mathrm{~d}$ & Posttest & $\mathrm{t}$ test & $\mathrm{t}$ table \\
39.9 & 56.25 & 19.04 & 4.017 & 2.132 \\
& & & & \\
\hline
\end{tabular}

From the explanation about theanalysis of the result calculation, $t$ test value $(4,107)$ was greater than the table $(2,132)$.

Analyze the effects of the suggestopedia method with wordwall picture on the students' interest in learning English

the researcher analyzing the students' interest in learning English specially vocabulary based on the students' quistionnaire which distributed after the treatment on 18 August 2016 and observational checklist that full fill by the researcher based on her observation during the lesson. After calculating the data, the researcher categorized the students interest used Likert scale and classified the student interest.

Respondent Questionnare score

\begin{tabular}{|l|l|}
\hline 1 & 4.6 \\
2 & 4.6 \\
3 & 4.3 \\
4 & 5 \\
\hline
\end{tabular}

Vol. 1 No. 2 March 2018

\begin{tabular}{|c|c|}
\hline 5 & 4.2 \\
& \\
\hline Total & 22.7 \\
\hline
\end{tabular}

From the table previously, itshowed that the highest interest score was5, the lowest interest score was 4,2 and thetotal of students' interest score was 22,7.The result showed that the students' levelof interest was 4,6 after being taught by using suggestopedia method with wordwall picture, it means that the students interest was high category.

Analyze The Correlation Between Students' Vocabulary And Interest In Learning English By Using Suggestopedia Method With WordwallPicture.

The researcher analyzed both data(Vocabulary test and questionnaire) to seethe correlation between students' interestand their vocabulary score by applying the formula of Pearson Product Moment Correlation. In this case, students' interestin English subject specially vocabulary is as independent variable (X) and students' Vocabulary Score is a dependent variable(Y). Below were the result of questionnaire about students' interest in English subject specially vocabulary and their vocabulary score. From the calculation of the data, it was known that $\mathrm{rxy}=0.97$ and $\mathrm{df}=5$; if we compare with table of " $r$ " values at the degree significance of $5 \%$ then the correlation between students' interest in 
English subject specially vocabulary and their vocabulary score is significant (rxy: $\mathrm{rt}$ $=0.97>0.878$ ).

Based on the table above it could be seen that the correlation index $(\mathrm{rxy}=0.97)$ is in the interval of $0.80-0.100$, thismeans that the correlation belongs to "very strong correlation". In other words, there is a positive correlation between variable Xand variable $\mathrm{Y}$. As mentioned before, from the result of calculation, the value of rxy is 0.97 ; $\mathrm{df}$ is 5 . If it is compared with the $\mathrm{rt}$ at the degree of significance 5\% (0.878), the correlation between students' interest inEnglish subject specially vocabulary andstudents' vocabulary score is significant( $\mathrm{rxy}: \mathrm{rt}=0.97>0.878$ ). So, the null hypothesis (HO) of the research is accepted and alternative hypothesis ( $\mathrm{Ha})$ is rejected.The meaning of this statement is the students'interest in learning English has a significant relationship or influence withstudents' vocabulary score.

\section{Discussion}

The first part of this research discussed the effectiveness of Suggestopedia method with word wall picture on development of students with disabilities learning competence in english vocabulary subject. The data obtained from the result of achievement tests (pre tests and post tests) provides reasonable explanation of the research. Based on the result on findings above, it is concluded that the difference of both means was statically significant. It means that the null hypothesis (HO) of the research is accepted and alternative hypothesis (HOE) is rejected, it proved that Suggestopedia

Vol. 1 No. 2 March 2018
Method with Wordwall Picture able to increase the vocabulary mastery of the students with disabilities learning of SMPLB Parepare.

It also could be interpreted that teaching vocabulary through Suggestopedia method with wordwall picture is affective and quite success than teaching vocabulary without using Suggestopedia method with wordwall picture. This is related to Mccoy, 1977 in Naomi Vega Nieves, in Bulgaria and in the Soviet Union who reported amazing success in foreign language acquisition with the suggestopedia method.

The second part of this research interpreted the students' interest in learning English especially vocabulary based on the students' quistionnaire and observation which did before and after the treatment. Relating to the finding above, It would be conclude that students' interest in learning English especially vocabulary experienced significant improvements after they had been taught using Suggestopedia method with wordwall picture. This is relating to Johnson (1982) cited in Prof Mohamed A. Zaid (2014) evaluated the effects of using collective relaxation techniques on the spelling performance of young learners. She used the experiment on separate experimental and control groups and could prove that low brain functioning students improved significantly with suggestopedia procedures. The overall results indicated favourable effect on both poor and good spellers.

As the conclution of the questionnaire result, it showed that the students' motivation increased. It means that Suggestopedia method with wordwall 
picture affect the students vocabulary mastery in learning English, it could also be seen from the activities they followed in the class actively. It was compatible either with the students' response when the teaching learning process is going on, they did the teacher's commands perfectly. It gave positive affect to their interest inleaming language, especjally English vocabulay.

The last part discussed the correlation between students' vocabulary and interest in learning English by using suggestopedia method with wordwall picture. Based on the analysis of the findings, there is a significant correlation between the students' interest and their vocabulary score. The researcher interprets the strong correlation is interest.

Students who had an interest in learning English specially vocabulary, they will give a high energy and motivation in learning, then the students will be happy and enjoy the activity more actively. In others hand, the teacher get the students' interest by the way of her teaching. Students who have a high interest try to pursue knowledge more than who have the low one. They tend to be more attentive in learning the lesson. They enjoy and ready to do the task given by the teacher. They are motivated to enrich they vocabulary.

\section{CONCLUSION AND SUGGESTION}

\section{A. Conclusion}

According to the description of the data that mentioned in the previous chapter, the results of this research revealed the improvements áontributed by the implementation of Suggestopedia method with wordwall picture in the teaching and

Vol. 1 No. 2 March 2018 learning process of English of SMPLB Negeri Parepare as follows:

1. The increasing of the students' test result after learning the vocabulary using Suggestopedia method with wordwall picture is proved that the use of Suggestopedia method with wordwall picture in teaching learning process is important for student's achievement. Besides Suggestopedia method as a creative method to make the students more focus, Word walls displaying previously taught vocabulary words provide a variety of benefits for students with learning disabilities. For example, having these words in a student's working environment can provide more exposures to important vocabulary and can allow for better retention. Additionally, students may use the words more often during discussion if they can see them, as well as use these terms in their writing without having to worry about the words' spelling.

2. Suggestopedia method with word wall picture were believed to be effective to improve the students' interest. They were able to engage the students' attentions and focus during the teaching and learning process of English lesson. Besides, the using wordwall picture could provide the students illustrations and ideas in their minds. The using music in Suggestopedia method could provide various fun learning activities so they decreased the students' boredom during their learning.

3. The correlation between students' interest in English subject specially vocabulary and students' vocabulary 
score is significant The meaning of this statement is the students'interest in learning English has a significant relationship or influence with students' vocabulary score

\section{B. Suggestion}

The writer would like to give somesuggestions which hopefully thesesuggestions would be useful for thestudents, teachers, the school, the otherresearcher, and the government.

1. Students

English as a second language seemsdifficult to learn if there is no wouldand motivation to learn it. Students ingeneral should encourage themselvesto learn more, to ask what they do notunderstand and to learn as much aspossible.

2. Teachers

The teacher should know how toenhance their ability in teaching andto develop a good athmosphere in theclass, so that the students learn at ease and comfortably in their class. Beside that, the teacher should be selective and creative in choosing appropriate materials to improve students vocabulary mastery and to enhance students' interest in learning English. The fact that Suggestopedia mehod with wordwall picture had a positve effect to our students' vocabulary improvement

3. The other researcher This research study is aimed at improving the students' vocabulary mastery. However, there were still some problems which were not yet solved.
Related to the focus of the study, it is advisable that the results of the study could be used as one of references for the other researchers who conduct the similar studies related to the development of the students' vocabulary mastery. But in other case, the result of this study could not suitable as a method for others disabilities such as autism, Audiotory Processing Disorder, Dyscalculia, Dysgraphia, and Language Processing Disorder. Therefore, the next researcher must to find out the way to teach other disabilities through Suggestopedia method.

\section{BIBLIOGRAPHY}

Ainley, M., Hidi, S., \& Berndorff, D. (2002). Interest, learning, and the psychological processes that mediate their relationship. Journal of Educational Psychology, 94, 545561.

American Speech-Hearing-Language Association website http://www.asha.org/public/speechjdi sorders/childsandl.htm

Brown, H.,D. (2007). Teaching by Principles - An Interactive Approach to Language Pedagogy. Pearson Education, Inc.

Brown, H.,D. (2001). Teaching By Principles: An Interactive Approach To Language Pedagogy, Second= Edition. New York. Longman

Brown, H.,D. (1987). Principles of language learning and teaching. Englewood Cliffs, New Jersey, Prentice Hall 
Bamiou, D-E, F. E. Musiek, and L. M. Luxon. Aetiology and Clinical Presentations of Auditory Processing Disorders-A Review 85.5 (2001): 361-65. Archives of Disease in Childhood. 2001. Web. http://adc.bmj.com/content/85/5/361 .full

Butterworth, Brian. Dyscalculia Screener. Rep. London: NferNelson, 2003. Dyscalculie.com.Web.http://www.dy scalculie.comJdl binldyscalculia screener manual.pdf

Butterworth, Brian. "Foundational Numerical Capacities and the Origins of Dyscalculia."Trends in Cognitive Sciences 14.12 (2010): 534L 41. National Center for Biotechnology Information. U.S. National Library of Medicine.

Web.http://www.ncbj.nlmjijh. gov/pub med/2 0971676.

Dyscalculia: Key Facts for Parents." Mathematicaibra in. corn. NferNelson Publishing. Web. httpj/www.mathematicalbrajn.comlpd f/NFER.pdf

Fletcher, Jack.Learning Disabilities: From Identjfication to Intervention. New York: Guilford, 2007. 2 17-25. Print.

Henderson, Anne. Dyslexia, Dyscalculia and Mathematics: A Practical Guide. 2nd ed. London: Routledge, 2012. Print.

Larsen. F. D (1986). Techniques And Principles In Language Teaching. New York. Oxford Exprees.

Gay, L.R. (1981). Educational Research. Comp etencies For Analysis and

Vol. 1 No. 2 March 2018
Aplication. Second Edition. USA. Charles, E. Mirril Publishing Company

Gay, L. R.Educational research : competencies for analysis and applications/L.R. Gay, Geoffrey E. Mills; Peter Airasian. - 1 0th ed

Johnson, P.L. (1982). The effect of group relaxation exercises on second- and sixth grade children 's spelling scores, Journal of accelerative learning and teaching, 7(3), 239-253

Krathwohl D. R. .Methods of Educational and Social Science Research: An Integrated Approach, by (2nd cd., p. 27), 1 998,Reading, MA: Addison Wesley.

LeCompte M. D. and Schensul, J. J. Designing and Conducting Ethnograp hics, Research: Vol. 1, Ethnographer 's Toolkit,p. 94, (C1999, Lanham, MD: AltaMiralRoman \& Littlefield. Reprinted with permission.

Lozanov, G. (1978). Suggestologv and Outlines on Suggestopedy. New York:Gordon and Breach

Lozanov, G. and Gatera, E. (1988).The foreign language teacher 's suggest opedic manual.New York: Gordon and Breach Science Publishers.

Lozanov, G. (1991 ).Suggestological realization and development of the global approach inforeign language teaching. The Journal of the Society for Accelerative Learning and Teaching, 16 (2), 151-156.

Lozanov, G. (1992).Suggestology and outlines of suggestopedy. (7th ed.). New York:Gordon and Breach Science Publisher 
Larsen - Freeman, D. and Marti Anderson. 2011. Techniques \& Principles in Language Teaching. United Kingdom: Oxford University Pres

Marzano, R. J. (2004). A six-step process for teaching vocabulary. In R. J. Marzano (Ed.), Building background knowledge for academic achievement. Alexandria, VA: Association for Supervision and Curriculum Development

McCoy, K. W. (1977).Suggestology as an effective language learning method. Paperpresented at the Annual Mountain Interstate Foreign Language Conference. (Eric Document No. Ed 145 722)

M.S. Rosenberg, D.L. Westling, J. McLeskey, Special Education for Today's Teachers: An Introduction, 2008 edition, p. 207-2 10

McCarten, Jeanne. 2007. Teaching Vocabulary (Lesson from the Corpus, Lessons for the Classroom). USA: Cambridge University Press

Nonverbal Learning Disorder Syndrome." Spinabifidasupport.com.

HydrocephalusAssociation.Web. hËi //www.spinabifidasupport.commnvld syndrome.htm

Priyatmojo, A.S. 2009. Suggestopedia as a Method for Teaching Speaking for Young Learners in a Second Language Classroom. Semarang State University: Unpublished Thesis

Richards, Jack C. and Theodore S. Rodgers (1986). Approaches and methods in language teaching: A description and analysis. Cambridge: Cambridge University Press

Ranpura, Ashish, et al. "Developmental Trajectories of Grey and White Matter in Dyscalculia." Trends in Neuroscience and Education 2.2 (2013): 56 - 64. Science Direct. Web. http://www.mathematicalbrain. comlpdf72013RANPURETAL.PDNa tional Institutes of Health Medline Plus http://www.nlm.nih.gov/medlineplu s/ency/article/00 1545 .htm

Rourke, B. P. (1982). Central processin deficiencies in children: Toward a developmental neuropsychological model. Journal of Clinical Neuropsychology, 4, 1-18.

Rourke, B. P. (1987). Syndrome of nonverbal learning disabilities: The final common pathway of whitematter disease/dysfunction? The Clinical Neuropsychologist, 1, 209234.

Rourke, B. P. (1988). Socio-emotional disturbances of learning-disabled children. Journal of Consulting and Clinical Psychology, 56, 801-810.

Read, John. 2000. Assessing Vocabulary. UK: Cambridge University Press

Riduwan and Akdon. (2002). Rumus dan Data dalam Analisis Statistika. Bandung. Alfabeta. p. 13

Radle, Paul. 2008. Suggestopedia. 27 Jan.2009<http://www.vtrain.net/lang sugg.htm>.

Schuster, D. H. (1976). A Preliminary evaluation of the suggestiveaccelerative Lozanov method of teaching beginning Spanish. The 
Journal of Suggestive

AccelerativeLearning and Teaching, $1(1), 32-51$.

Shalev, Ruth. 'Developmental Dyscalculia." Journal of Child Neurology 19.10 (2004): 765-71. Sage Journals. Web.

Schuster, D. (1979).Evaluatjons of the suggestive, accelerative Lozanov teaching method in teaching various subjects to low and mid socioeconomy school students. (ERIC) Document No. ED183 015

Setyadi.B.(2006). Teaching English As Foreign Language .Yogyakarta. Graha Ilmu.

Sugiyono. 2010. Statistika untuk Penelitian. Bandung.Alfabeta

Rhalmi, M. (2009). The origin of Suggestopedja. Retrieved 16 January 2O15fromhttp://www.myEnglishpag es.com/blog/suggestopedja/\#

Visual Processing Disorder." LDANL.org. Learning Disabilities Association of Newfoundland and Labrador. Web. http://www.ldanlor1da/7gvpĐ

Villamin, A.M., Salazar, E.L., Bala, E.C., \& Sunga, N.R. (1994). Innovative strategies in communication arts. Quezon City, QC: Phoenix Publishing House, Inc.

Viachos, F. \& Karapetsas, A. (2003). Visual Memory Deficit in Children With Dysgraphia. Perceptual and motor skills, 97, 1281-1288.

Wilson, Anna J. "Dyscalculia Primer and Resource Guide." OECD. org. Organisation for Economic Cooperation and Development. iaPrimerandresourcegujdeh 